\title{
Comportement curieux de puits dans des terrains saturés d'eau
}

\author{
PAR 'T. BLENCH, M. ASCE

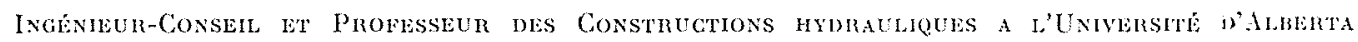

English text, p. 11

Nous décrirons, ci-dessous, une simple démonstration expérimentale, effectuée dans le Laboratoire d'Hydrogéologie de l'Université d'Alberta. C'est M. E.-S. Crump, ancien ingénieur en chef du Département d'Irrigation du Punjab, qui l'imagina en 1939, afin d'éclairer un problème soulevé à propos d'une étude sur les quantités d'eau en jeu lors de la saturation d'une zone irriguée par canaux couvrant environ 1.600 .000 hectares.

Des études sur la saturation avaient déjà été poursuivies dans cette région en observant pendant plusieurs années la corrélation entre les fluctuations des niveaux dans les puits et celles de la pluviosité (les variations dans les apports d'eau d'irrigation n'étaient pas suffisamment prononcées). Malheureusement, les expérimentateurs de cette époque ignoraient le phénomène de la dépression capillaire; pour eux, les variations des niveaux dans les puits correspondaient aux quantités d'eau souterraines, compte tenu de la porosité du sol. Leurs idées concernant le degré de saturation des terrains à la suite des apports de l'irrigation étaient donc erronées; il en résultait une fausse estimation des quantités d'eau mises en jeu.

Lors des recherches ultérieures, on eut connaissance du comportement curieux de certains puits dans la région du Zuidersée en Hollande : de faibles pluies causaient des remontées brusques des niveaux dans les puits, remontées beaucoup trop fortes pour qu'elles puissent correspondre à la quantité d'eau tombée, compte tenu de la porosité du sol. Les explications données à cette époque ne paraissant pas satisfaisantes, une expérience fut montée consistant à retirer, fraction par fraction, l'eau d'un modèle réduit de «terrain saturé » contenu dans un bidon d'huile de 200 litres. L'expérience a confirmé l'hypothèse selon laquelle le phénomène est dû à la destruction des ménisques à la surface de la frange capillaire lors des pluies.
La figure 1 montre le modèle. Le bidon contient du sable submergé L'air a été chassé en tapant sur le bidon. La granulométrie du sable correspond à une remontée capillaire convena-

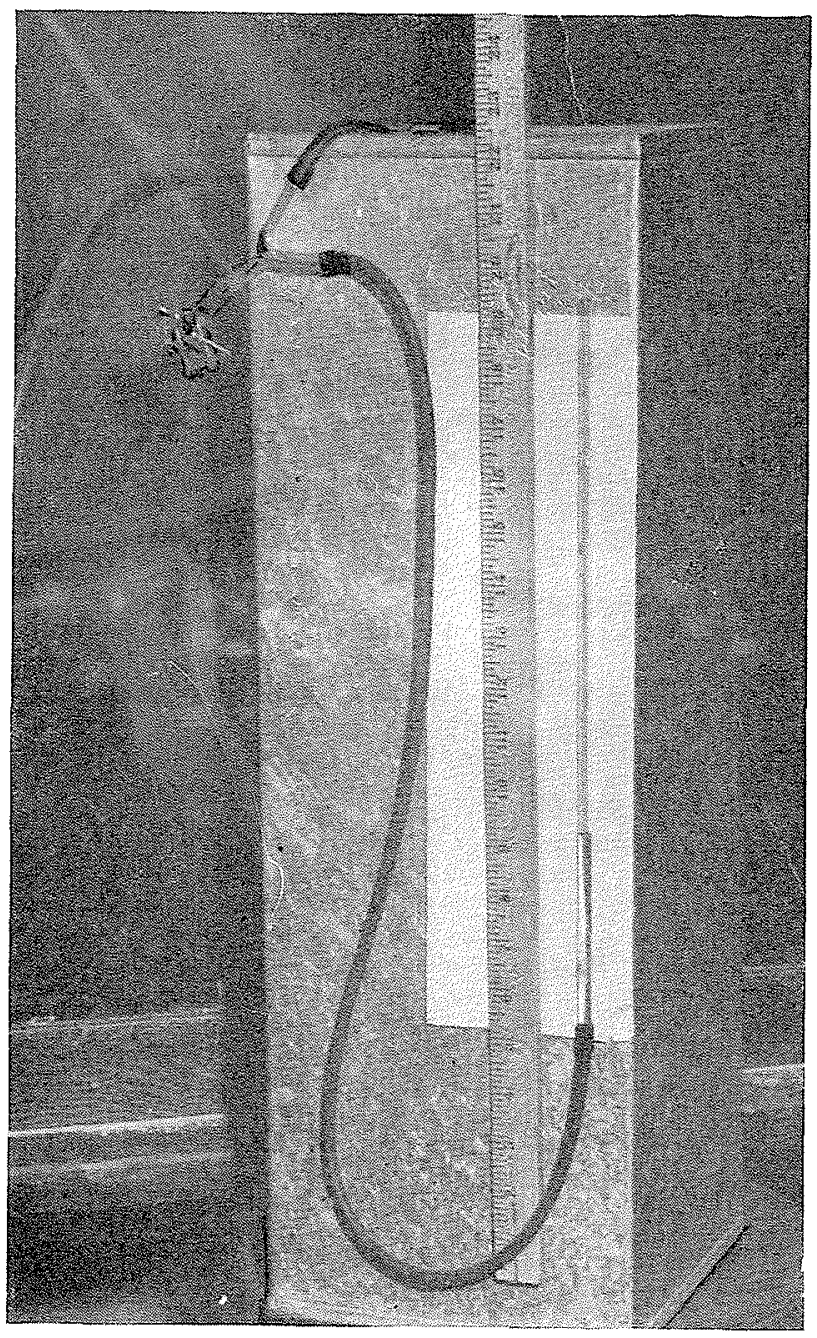

FiG. 1 
ble, égale à environ $45 \mathrm{~cm}$. Le tuyá d'un manomètre indiquant le niveau phréatique passe par le fond du bidon (pour éviter l'accumulation d'air pendant l'expérience). L'eau de surface pent ètre enlevée par siphonnage au moyen d'un deuxième tuyau.

L'eau est prélevée au moyen du siphon par petites fractions soigneusement mesurées; la descente du manometre est notée sur un diagramme en fonction du volume d'eau prélevé (voir fig. 2, cqui n'est pas à l'échelle). Aussi longtemps que le sable est submergé, les petits prélèvements ont un effet négligeable sur le manomètre. Quand la surface montre pour la première fois des taches seches, le manometre commence à bouger d'une façon appréciable. Vers le moment où les dernières taches mouillées disparaissent, le manomètre tombe à une vitesse qui est environ quarante fois celle qui correspondrait au volume enlevé, compte tenu de la porosité.

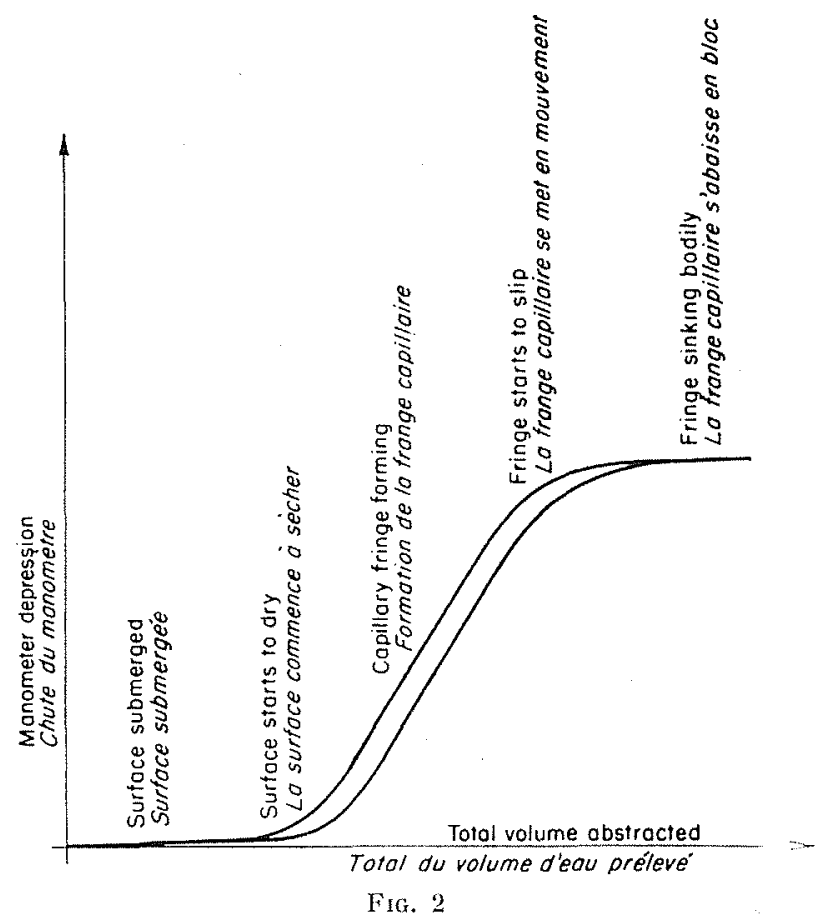

Le manomètre tombe d'environ $45 \mathrm{~cm}$; ensuite la vitesse de descente diminue jusqu'à ce que, finalement, cette vitesse redevienne négligeable. Dans le processus inverse (apport d'eau), la courbe revient à son point de départ en décrivant une petite boucle d'hystérésis; celte boucle est d'autant plus grande que l'expulsion de l'air a été moins complète.

Quand on arrête l'opération quelque part sur la pente rapide de la courbe de la figure 2 , et qu'on mouille la surface avec quelques gouttes d'eau tombées de la main, en imitant une faible pluie, le manomitre monte d'environ $5 \mathrm{~cm}$ en l'espace de quelques secondes.

L'explication générale est la suivante : quand la surface s'assèche par suite de faibles prélèvements d'eau, il se forme des ménisques dans les pores et l'eau souterraine se trouve soumise à une dépression : le niveau phréatique s'abaisse d'une certaine hauteur correspondant à la remontée capillaire caractéristirjue du terrain. Dès que cette limite est atteinte, toute la frange capillaire descend en bloc et les mouvements du niveau phréatique, dus juscu'à ce moment à des fluctuations de pression, reflètent désormais les mouvements de la nappe. Quand les ménisques affleurent la surface du sol, quelques gouttes d'eau en détruisent suffisamment pour affecter d'une façon appréciable la valeur de la dépression ef pour provocuer une saute de niveau dans le puits.

Cette expérience fit l'objet d'une variante intéressante consistant à reproduire un phénomène mentionné lors du grand tremblement de terre de Bihar, en 1938 environ. Selon les reportages, l'eau aurait jailli par-dessus les margelles des puits. La première expérience avait négligé que le sable sédimenté dans l'eau retient encore beaucoup d'air. Quand une large boucle d'hystérésis révéla la présence probable d'air, le bidon fut battu avec un tuyau en fer. On n'observa pas seulement un jaillissement de l'eau par-dessus le bord supérieur du tube vertical qui avait remplacé le siphon de la figure 1; on vit la surface du sable se tasser et se couvrir d'écume. 


\title{
Anomalous Behaviour of Wells in Waterlogged Areas
}

\author{
T. BLENCH, M, ASCE, \\ Consulting Engineer and Associate Professor of Civil Engineering. \\ University of Alberta
}

See French text for illustrations (p. 9)

The simple experiment outlined below is being used as a laboratory demonstration in the University of Alberta in soil-watel physics. It was devised originally by Mr. E.S. Crume, former Superintending Engineer of the Punjab Irrigation Department, in 1939, to settle a point that arose in an investigation of the quantitative causes of waterlogsing in a canalized watershed with some four million acres of irrigation.

Waterlogging in that area had been investigated previously by several year's' correlation between fluctuations of well levels and fluctuations of rainfall (since irrigation load does not vary sufficiently for the purpose). Unfortunately, the analysts of that time were unaware of the phenomenon of capillary pressure release, and attributed to unit well-level movement a depth of water obtained by multiplying the movement by the fractional porosity of the soil. Consequently an erroneous idea was obtained of the amount of water involved in the waterlogging rise following the introduction of irrigation; this, in turn, caused a wrong assessment of the quantitative causes.

During the later investigation information was obtained of the peculiar behaviour of wells in the Zuyder Zec area of the Netherlands, where trifling rainfalls caused well levels to jump out of all proportion to what could be explained in terms of the rainfalls and the effective porosity of the soil. As the explanation then given did not seem adequate an experiment was made of abstracting water by stages from a "waterlogged soil" in a 45-gallon oil drum; it confirmed the belief that the explanation lay in the destruction of the meniseuses at the top of the capillary fringe when rain water fell on them.

Tho present experiment will be understood from Fig. 1. The container is filled to a convenient level with sand and water, so that water stands freely on the surface. The container is beaten well to vibrate air out of the waterlogged sand. The sand is of a srade that will give, for convenience, a capillary lift of about 18 inches. A manometer tube is brought from deep in the sand (to prevent it drawing air during the experiment) to the outside to record "well-level". Another tube is provided to act as a siphon from which water can bo extracted from the "water-table".

Water is extracted through the siphon tube in small measured amounts. and the manometer drop is plotted against quantity extrated, as in Fig. 2, which is not to scale. So long as water stands on the surface the small extractions have negligible effect on the manometer. When the surface starts to show patches of dryness the manometer starts to move appreciably. By the time the surface has ceased to show patehes of wetness the manometer is falling at a rate about 40 times as fast as can be explained in terms of effective porosity and quantity extracted. It falls for some 18 inches, and then the rate of drop decreases till, ultimately, the rate of drop is negligible again. Reversal of the process, by replacing water, brings the curve back by a narrow "hysteresis" loop; if air extraction has been poor the loop will be broad.

If the manometer is stabilized somewhere on the rapid slope of the curve of Fig. 2, and then the surface of the soil is sprinkled with drops of water from the experimenter's fingers-to represent a trifling rain-the manometer will rise, in the course of a few seconds, by an inch or two.

The general explanation is that, as the surface dries out, due to a very small abstraction of water, meniscuses form in the soil spaces and produce a negative pressure in the soil water, thereby lowering the surface of atmospherie pressure in the soil-water (i.e. the watertable) by an amount limited by the capillary lift of the soil. Once the limit has been reached the whole capillaly fringe moves dorw bodily, and the well movement -previously a manometric pressure record-becomes indicative of the movement of water. When the meniscuses are still at the surface a slight sprinkling of water will destroy sufficient of them to alter the general negative pressure appreciably and cause a jump in water-table level.

An interesting happening in the original experiment was the reproduction of a reported occurrence of the sreat Bihar earthquake of circa 1938. Water was reported to have sushed up over the tops of wells. The first experiment did not appreciate that sand deposited in water still holds considerable quantities of air. When a broad hysteresis loop indicated that air was probably still present, the oil barrel of the experiment was beaten well with a steel pipe, and not only did water gush over the top of the stand-pipe that was being used instead of the siphon of Fig. 1 , but the sand surface settled and became covered with froth. 